\title{
THE INDUCTION OF SECOND-GROWTH IN POTATO TUBERS
}

\author{
K. B. A. BODLAENDER, C. LUGT and J. MARINUS \\ Instituut voor Biologisch en Scheikundig Onderzoek van Landbouwgewassen (I.B.S.), Wageningen, \\ Netherlands
}

Summary, Zusammenfassung, Résumé, p. 69

\section{INTRODUCTION}

\subsection{Occurrence of second-growth}

Second-growth in potato tubers occurred in many places in the Netherlands during the summers of 1957 and 1959, especially on the heavy clay soils in the western part of the country (LUGT, 1960, 1961). This second-growth was presumably due to the special weather conditions in these summers. During the first part of these growing seasons severe drought inhibited growth of the potato plants. At the end of June a period of high temperature occurred in both years; in 1957 it was followed by lower temperatures with heavy rains and in 1959 by rather high temperatures with some irregular rainfall, but water was generally short throughout.

Second-growth phenomena have also been observed in other countries in these and other years, e.g. in France (LaPLAUD, 1905; SCHRIBAUX, 1921), Germany (FISCHNICH, 1959), Austria (Steineck, 1952), U.S.A. (Bushnell and Welton, 1931; Kraus, 1945; SPARKS, 1958), and Ireland (MURPHY, 1936). With most examples of second-growth authors have observed periods of drought followed by rainfall during the growing season; high temperatures have also been mentioned.

\subsection{Types of second-growth}

The following types of second-growth can be distinguished: 1. elongated tubers 2 . bottlenecks 3. knobby tubers or gemmation 4. chain-tuberization or secondary tuber formation and 5. sprouted tubers, i.e. tubers which have sprouted without forming a secondary tuber. The first four types have a primary and a secondary tuber or part of a tuber.

Several authors consider these different forms of second-growth to be caused by the same factors. Which type of second-growth will occur, is - according to them determined by the degree of maturation of the tubers at the time when rain again supplies water for growth. This publication treats only the general cause of secondgrowth phenomena. How different types of second-growth are formed will be discussed in a further paper.

\subsection{Explanation of the induction of second-growth}

There are several ways in which second-growth - as it occurs in potato fields - may originate and some of these are suggested by the authors mentioned in section 1.1.:

Received for publication 9th September, 1963. 
K. B. A. BODLAENDER, C. LUGT and J. MARINUS

I. High temperature breaks the dormancy of tubers. The tubers begin to sprout and the sprouts or stolons produced eventually form new tubers. Tuber dormancy, defined as the absence of elongation of tuber buds, commences with tuber initiation.

II. Drought stops tuber growth prematurely and induces tuber maturation and dormancy; this dormancy is broken by high temperature and when water is later supplied, sprout growth and new tuber growth will occur.

III. Tuber growth is temporarily inhibited by the absence of water and minerals during the drought period; there is then no dormancy of tuber buds, and when water and minerals are again available to the plants, the tubers sprout and/or tuber growth is continued leading to the formation of secondary tubers and bottlenecks.

IV. Severe drought breaks dormancy and induces sprouting of tubers.

The second and third explanations are favoured by the observation that plots, irrigated during the whole growing season, often showed much less or no second-growth at all as compared to non-irrigated plots. Sometimes, however, the reverse seemed to be the case (BaArs, 1962; Corey and Meyers, 1955; Kraus, 1945; Nielsen and Sparks, 1953). LUGT (1960) and others, however, have observed sprouts on tubers in the soil during the drought period and before the new rains had fallen; this observation seems to exclude the third explanation.

\subsection{Aim of the experiments}

This investigation has been carried out to induce second-growth in potato tubers experimentally under controlled conditions in glasshouses in order to explore which factor or combination of factors causes second-growth.

\section{METHODS}

\subsection{General conditions and materials}

Experiments were carried out during 1959, 1961 and 1962 during the summer under natural daylength conditions. Only the 1962 experiment will be discussed in detail here.

The plants were generally grown in humous sandy soil (in one case in white river sand) in large asbestos bins $(90 \times 70 \times 40 \mathrm{~cm})$. These bins were placed on cars which could be moved from one glasshouse into another so that the temperature during development could be changed. Each treatment consisted of two bins, each with 6 plants (tuber size $35-45 \mathrm{~mm}$ ). In one experiment to be discussed later in section 3.5, the plants were grown in Mitscherlich pots, one plant per pot and 4, (3 or 6) plants per variety and temperature.

\subsection{Temperature}

In most experiments all plants were grown at the same temperature from emergence until treatments started after tuber initiation ( $T_{1}$ in TABLE 1,2 and 3$)$. The plants were then divided into groups and placed in separate glasshouses at different temperatures, 
$16^{\circ}, 22^{\circ}, 27^{\circ}\left(28^{\circ}\right)$ or $32^{\circ} \mathrm{C}$. After a month at $27^{\circ}\left(28^{\circ}\right)$ or $32^{\circ} \mathrm{C}$ (designated as $\left.\mathrm{T}_{2}\right)$, some plants were transferred to the glasshouse at $16^{\circ}$ or $22^{\circ} \mathrm{C}$, while other plants remained in the glasshouse at the high temperature until the final lifting (the last period was indicated as $\mathrm{T}_{3}$ ).

The aim was to keep the temperatures constant during day and night; on days with bright sunshine, however, the temperature rose some degrees above the normal level during a few hours in the middle of the day, especially at the medium temperature $\left(22^{\circ} \mathrm{C}\right)$; the lowest temperature $\left(16^{\circ} \mathrm{C}\right)$ could be maintained quite well by mechanical cooling of the glasshouse. The temperatures mentioned were those of the air 50-100 $\mathrm{cm}$ above the plants; the difference between this temperature and air temperature between the plants did not exceed $2^{\circ} \mathrm{C}$.

In the 1962 experiment leaf and soil temperatures were measured. During the day, especially in bright sunshine, these temperatures were about $2^{\circ} \mathrm{C}$ lower when there was an ample water supply than in the dry soil treatment.

\subsection{Water supply}

All plants, except those in the drought treatments, received ample water by maintaining a water table at the bottom of the bins or pots. These plants never showed any sign of water shortage. The plants of the drought treatments received no water for several weeks until the leaves had wilted for some days; water was then again supplied. This was repeated several times until the plants died in treatments 3 and 7 (TABLE 1).

\subsection{Manuring}

The plants grown in humous sandy soil were manured with ammonium nitrate limestone, superphosphate, potassium sulphate and magnesium sulphate, in quantities corresponding to $60 \mathrm{~kg} \mathrm{~N} / \mathrm{ha}$ (in the 1962 experiment $100 \mathrm{~kg} \mathrm{~N} / \mathrm{ha}$ ), $120 \mathrm{~kg} \mathrm{P}_{2} \mathrm{O}_{5} / \mathrm{ha}$, $160 \mathrm{~kg} \mathrm{~K}{ }_{2} \mathrm{O} / \mathrm{ha}$ and $100 \mathrm{~kg} \mathrm{MgO} / \mathrm{ha}$. The plants grown on white river sand received in addition a nutrient solution containing calcium nitrate, potassium nitrate, potassium di-hydrogen phosphate and magnesium sulphate, in quantities corresponding to $20 \mathrm{~kg}$ $\mathrm{N} /$ ha, $70 \mathrm{~kg} \mathrm{P}_{2} \mathrm{O}_{5} / \mathrm{ha}, 47 \mathrm{~kg} \mathrm{~K} 2 \mathrm{O} / \mathrm{ha}$ and $40 \mathrm{~kg} \mathrm{MgO} / \mathrm{ha}$, a concentrated solution of chelated iron and the following trace-elements: boron, copper, manganese, molybdenum and zinc.

In the 1962 experiment an attempt was made to imitate nitrification by giving an additional supply of nitrogen to plants grown on white river sand (treatments 9 and 10 , indicated as $+\mathrm{N})$ during the second period of growth $\left(\mathrm{T}_{2}: 25 / 5-25 / 6\right)$. This additional supply was given as calcium nitrate in four, weekly applications, each corresponding to $10 \mathrm{~kg} \mathrm{~N} / \mathrm{ha}$.

\subsection{Observations}

In the early and late liftings all tubers of the first generation were classified into the following groups: 1 . unsprouted tubers (= tubers without a sprout, secondary tuber or secondary tuber part); 2. sprouted tubers (= tubers with one or more sprouts, but without a secondary tuber or tuber part); 3. primary tubers (= tubers with one 
K. B. A. BODLAENDER, C. LUGT and J. MARINUS
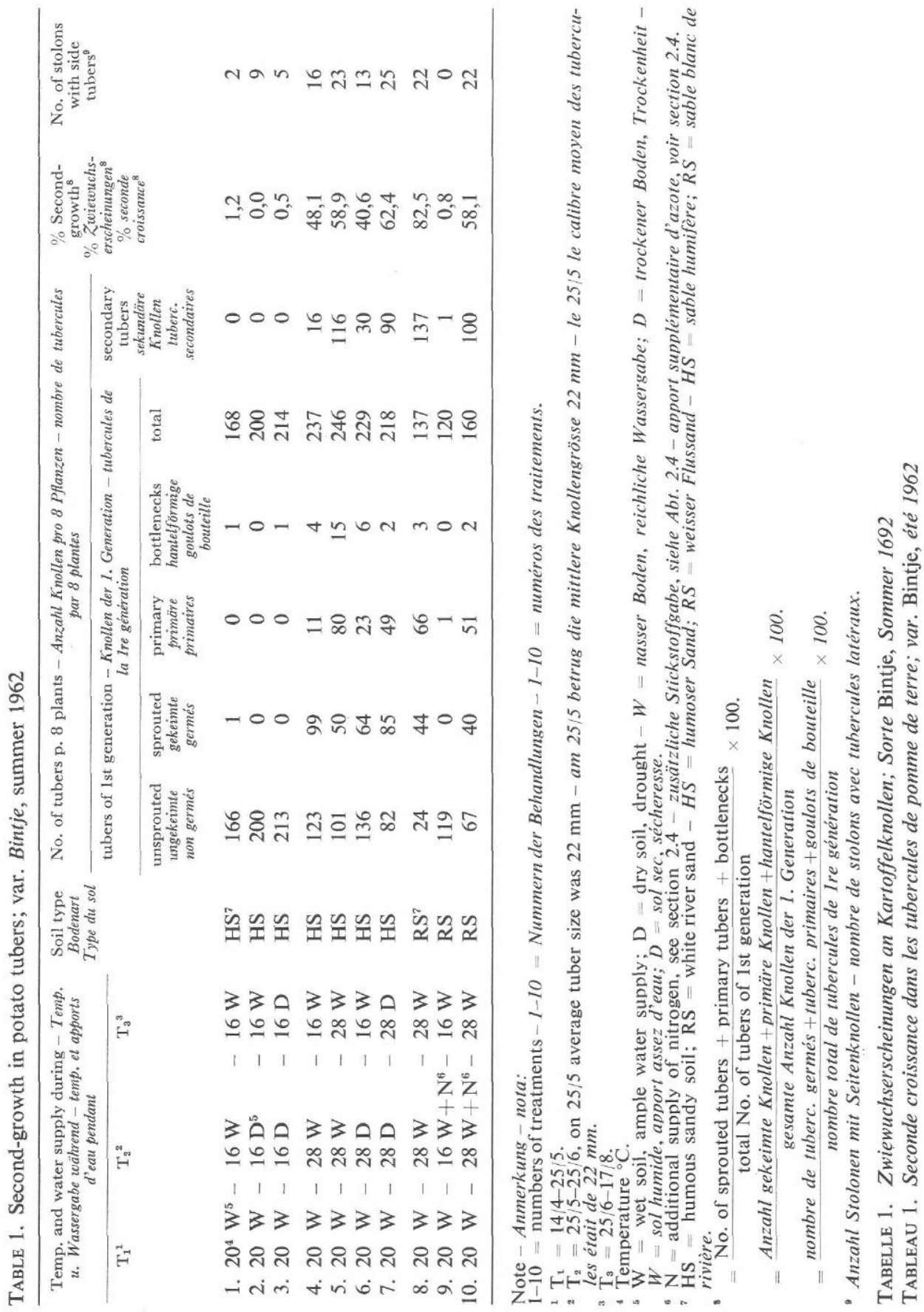


\section{THE INDUCTION OF SECOND-GROWTH IN POTATO TUBERS}

or more secondary tubers with or without sprouts); 4 . bottlenecks (tubers with a primary and secondary tuber part). The extent of second-growth is indicated as percentage second-growth (TABLE 1).

In some experiments the number of secondary tubers was also counted and observations made on stolon growth, stem elongation and decay of foliage.

\section{RESULTS}

\subsection{Induction of second-growth in potato tubers}

Second-growth in potato tubers was induced by high temperature in 7 experiments (out of 8), and was not induced by drought in any of the 4 experiments, in which this treatment was investigated. The results of an experiment carried out in the summer of 1962 are shown in TABLE 1 . Second-growth did not occur at $16^{\circ} \mathrm{C}$; at the high temperature of $28^{\circ} \mathrm{C}$, however, a large percentage of the total number of first-generation tubers showed second-growth. This was induced by high temperature with or without ample water supply (treatments 4, 5, 6 and 7). Drought only did not cause secondgrowth (treatments 2 and 3 ).

It might be assumed that high temperature promotes nitrification in humous sandy soil and that second-growth in potato tubers is due to the fresh nitrogen supply formed in this way. This, however, was not so as plants growing in white river sand also showed a large percentage of second-growth (treatment 8). A fresh supply of nitrogen to plants growing in white river sand during the treatment period did not cause or increase second-growth (treatments 9 and 10). It should be considered, however, that the total nitrogen supply to these plants was not large.

The duration of the heat period influenced the degree of second-growth. In the 1962 experiment the plants grown during a month at $28^{\circ} \mathrm{C}$ showed at the final lifting many sprouted tubers (treatments 4 and 6); continuation of the high temperature (treatments 5 and 7) increased the number of tubers showing second-growth (sprouted tubers + primary tubers + bottlenecks). A similar increase was observed in an experiment carried out in 1961 with the variety Alpha (TABLE 2, compare treatment 7 with the treatments 3 and 9). After a prolonged period of high temperature the number of secondary tubers was also much larger than after a relatively short period (TABLE 1, compare treatments 5 and 7 with treatments 4 and 6).

\subsection{Type of second-growth}

The type of second-growth found in the above-mentioned glasshouse experiments differed somewhat from those found in the field experiments in 1957 and 1959. In the field experiments the secondary tubers found were quite large, often of the same or larger size than the primary ones. In the 1962 glasshouse experiment, however, many sprouted tubers without secondary tubers were found at the final lifting - the plants had then died - and the secondary tubers were generally small (their average weight was $6 \mathrm{~g}$ ). This may have been due to the relatively large number of tubers per plant and to the continuation of the high temperature, the induction of second-growth and 
TABLE 2. Second-growth in potato tubers; var. Alpha, summer 1961

\begin{tabular}{|c|c|c|c|c|c|c|c|c|c|}
\hline \multirow{2}{*}{\multicolumn{4}{|c|}{$\begin{array}{c}\text { Temperature during } \\
\text { Temperatur während } \\
\text { Température pendant } \\
\left({ }^{\circ} \mathrm{C}\right)\end{array}$}} & \multicolumn{5}{|c|}{$\begin{array}{l}\text { No. of tubers of } 1 \text { st generation p. } 12 \text { plants - Anzahl Knollen der } 1 . \text { Generation } \\
\text { pro } 12 \text { Pflanzen - nombre de tuberc. de Ire géneration par } 12 \text { plantes }\end{array}$} & \multirow{3}{*}{$\begin{array}{l}\text { \% second- } \\
\text { growth }^{6} \\
\text { \% Zuiewuchs- } \\
\text { erscheinungen } \\
\text { \% seconde } \\
\text { croissance }^{6}\end{array}$} \\
\hline & & & & \multirow{2}{*}{$\begin{array}{l}\text { unsprouted } \\
\text { ungekeimte } \\
\text { non germés }\end{array}$} & \multirow{2}{*}{$\begin{array}{l}\text { sprouted } \\
\text { gekeimte } \\
\text { germés }\end{array}$} & \multirow{2}{*}{$\begin{array}{c}\text { primary } \\
\text { primäre } \\
\text { primaires }\end{array}$} & \multirow{2}{*}{$\begin{array}{l}\text { bottlenecks } \\
\text { hantelförmige } \\
\text { goulots de } \\
\text { bouteille }\end{array}$} & \multirow[t]{2}{*}{ total } & \\
\hline $\mathrm{T}_{1}$ & & $2^{2}$ & $\mathrm{~T}_{3}{ }^{3}$ & & & & & & \\
\hline 1. & 22 & $16^{4}$ & & 158 & 0 & 0 & 0 & 158 & 0,0 \\
\hline 2. & 22 & $22^{4}$ & & 186 & 0 & 0 & 1 & 187 & 0,5 \\
\hline 3. & 22 & $27^{4}$ & & 97 & 39 & 50 & 2 & 188 & 48,4 \\
\hline 4. & 22 & $32^{4}$ & & 144 & 23 & 37 & 15 & 219 & 34,2 \\
\hline 5. & 22 & 16 & $16^{5}$ & 166 & 0 & 0 & 0 & 166 & 0,0 \\
\hline 6. & 22 & 22 & $22^{5}$ & 176 & 11 & 3 & 16 & 206 & 14,6 \\
\hline 7. & 22 & 27 & $27^{5}$ & 122 & 35 & 63 & 14 & 234 & 47,9 \\
\hline 8. & 22 & 16 & $22^{5}$ & 143 & 3 & 0 & 2 & 148 & 3,4 \\
\hline 9. & 22 & 27 & $22^{5}$ & 113 & 37 & 31 & 8 & 189 & 40,2 \\
\hline 10. & 22 & 32 & $22^{5}$ & 166 & 23 & 8 & 23 & 220 & 24,5 \\
\hline
\end{tabular}

Note - Anmerkung - nota:

$1-10=$ numbers of treatments $-1-10=$ Nummern der Behandlungen $-1-10=$ numéros des traitements. ${ }^{1} \mathrm{~T}_{1}=5 / 5-6 / 6$.

${ }^{2} \mathrm{~T}_{2}=6 / 6-12 / 7$, on $6 / 6$ the average tuber size was $15 \mathrm{~mm}$ - am $6 / 6$ betrug die mittlere Knollengrösse 15 mm - le 6/6 le calibre moyen des tubercules était de $15 \mathrm{~mm}$.

$\mathrm{T}_{3}=12 / 7-17 / 8$.

4 Lifted on 12/7 - geerntet am 12/7 - arrachées le 12/7.

${ }^{5}$ Lifted on 17/8 - geerntet am 17/8-arrachées le 17/8.

${ }^{6}$ See tABle 1 - siehe TABelle 1 - voir TABLEAU 1.

TABELle 2. Zwiewuchserscheinungen an Kartoffelknollen; Sorte Alpha, Sommer 1961

TABLEAU 2. Seconde croissance dans les tubercules de pomme de terre; var. Alpha, été 1961

the formation of new tubers of the first generation. Plants grown on nutrient solution formed relatively large secondary tubers after heat treatment; this will be discussed in a further paper.

\subsection{Other effects of high temperature and drought}

The high temperature and drought treatments in the 1961 and 1962 experiments were started some weeks after tuber initiation (average tuber size 15 and $22 \mathrm{~mm}$ respectively). In these experiments, high temperature generally increased the total number of tubers of the first generation and drought at $16^{\circ} \mathrm{C}$ seemed to have the same effect (TABLE 1 and 2). This was due to the formation of new tubers (new tubers of the first generation, of course, decrease the percentage of second-growth). These new tubers could have been formed on new lateral stolons, the number of which was increased by high temperature, and perhaps also on new main stolons (TABLE 3). Sometimes new tubers also grow directly from the lateral growing points on main stolons bearing the apical tubers; plants which had grown for some weeks at high temperature had a much higher number of stolons with side tubers than plants grown at $16^{\circ} \mathrm{C}$ (TABLE 1). In an experiment with plants grown with nutrient solution, the initiation of these side tubers could be clearly seen after a period at high temperature (FIG. 1). 
THE INDUCTION OF SECOND-GROWTH IN POTATO TUBERS

TABLE 3. Influence of temperature on stolon development; var. Alpha, Summer 1961

\begin{tabular}{|c|c|c|c|c|c|c|c|}
\hline \multirow{2}{*}{\multicolumn{4}{|c|}{$\begin{array}{c}\text { Temperature during } \\
\text { Temperatur während } \\
\text { Température pendant } \\
\left({ }^{\circ} \mathrm{C}\right)\end{array}$}} & \multicolumn{3}{|c|}{$\begin{array}{c}\text { No. of stolons p. } 12 \text { plants - Anzahl der Stolonen pro } 12 \text { Pflanzen } \\
\text { nombre de stolons par } 12 \text { plantes }\end{array}$} & \multirow{3}{*}{$\begin{array}{l}\text { Total wt. of stolons }{ }^{4} \\
\text { Totalgew. der Stolonen }{ }^{4} \\
\text { Poids total des stolons }{ }^{4}\end{array}$} \\
\hline & & & & \multirow{2}{*}{$\begin{array}{c}\text { main stolons } \\
\text { Hauptstolonen } \\
\text { stolons principaux }\end{array}$} & \multirow{2}{*}{$\begin{array}{l}\text { branched stolons } \\
\text { verzweigte Stolonen } \\
\text { stolons ramifiés }\end{array}$} & \multirow{2}{*}{$\begin{array}{l}\text { side stolons } \\
\text { Seitenstolonen } \\
\text { stolons lateraux }\end{array}$} & \\
\hline & $\mathrm{T}_{1}{ }^{1}$ & $\mathrm{~T}_{2}{ }^{2}$ & $\mathrm{~T}_{3}{ }^{3}$ & & & & \\
\hline 5. & 22 & 16 & 16 & 312 & 10 & 12 & 34,3 \\
\hline 6. & 22 & 22 & 22 & 349 & 25 & 30 & 67,3 \\
\hline 7. & 22 & 27 & 27 & 469 & 21 & 28 & 161,5 \\
\hline 8. & 22 & 16 & 22 & 371 & 15 & 26 & 52,4 \\
\hline 9. & 22 & 27 & 22 & 331 & 24 & 38 & 97,3 \\
\hline 10. & 22 & 32 & 22 & 471 & 43 & 71 & 94,7 \\
\hline
\end{tabular}

Note - Anmerkung - nota:

5-10 = numbers of treatments - 5-10 = Nummern der Behandlungen $-5-10=$ numéros des traitements. 1,3 , s See TABLE 2 - siehe TABELle 2 - voir TABleau 2.

4 Fresh wt. in $\mathrm{g}$ per 12 plants - Frischgewicht in $\mathrm{g}$ pro 12 Pflanzen-poids frais en $\mathrm{g}$ par 12 plantes.

TABELle 3. Einfluss der Temperatur auf die Entwicklung der Stolonen; Sorte Alpha, Sommer 1961

TABLEAU 3. Influence de la température sur le développement des stolons; var. Alpha, été 1961

Accordingly, high-temperature treatment does not only induce second-growth in potato tubers, but also causes the formation of new side tubers, branching of the stolons, and the continued growth of some stolons. Plants grown at high temperature showed some very long stolons $(20-35 \mathrm{~cm})$. Obviously, the dominance of tubers at the end of the stolons is diminished by heat treatment.

High temperature also favours stem elongation and formation of new leaves: stems cease elongating sooner and are finally much shorter at $16^{\circ} \mathrm{C}$ than at $28^{\circ} \mathrm{C}$; the plants also die earlier at $16^{\circ} \mathrm{C}$ than at high temperatures (FIG. 2 and 3). Drought, however, inhibits stem growth. Regrowth at the top of plants has been observed after a heat treatment if stem elongation and the formation of new leaves had terminated before the high-temperature treatment started (FIG. 4). In the experiments mentioned above, stems were still elongating when the high-temperature treatments were started and continued during them.

\subsection{Other factors influencing the occurence of second-growth}

These results do not exclude the possible influence of other factors on the induction of second-growth in potato tubers. In an experiment with the variety Alpha a larger percentage of second-growth was found under long-day than under short-day conditions, 35 and $20 \%$ respectively of all tubers of the first generation showed secondgrowth (during the experiment periods of high temperature occurred in the glasshouse). In another experiment, carried out in a growth room with a constant temperature of $16^{\circ} \mathrm{C}$, constant light intensity and ample water supply, second-growth was also noted, a very large supply of nitrogen (corresponding to $600 \mathrm{~kg} \mathrm{~N} / \mathrm{ha}$ ) may have been the cause. Second-growth was also induced in potato tubers by adding gibberellic acid to the foliage or tubers (LIPPERT, RAPPAPORT and TIMM, 1958; Claver, 1960. and own experiments). 
Fig. 1. Formation of new side tubers after heat treatment $\left(32^{\circ} \mathrm{C}\right.$ for 2 weeks) on stolon with large apical tuber; the apical tubers also show second-growth phenomena. Plants were grown in nutrient solution in a growth room. The temperature was $16^{\circ} \mathrm{C}$ before and after heat treatment; var. Bintje

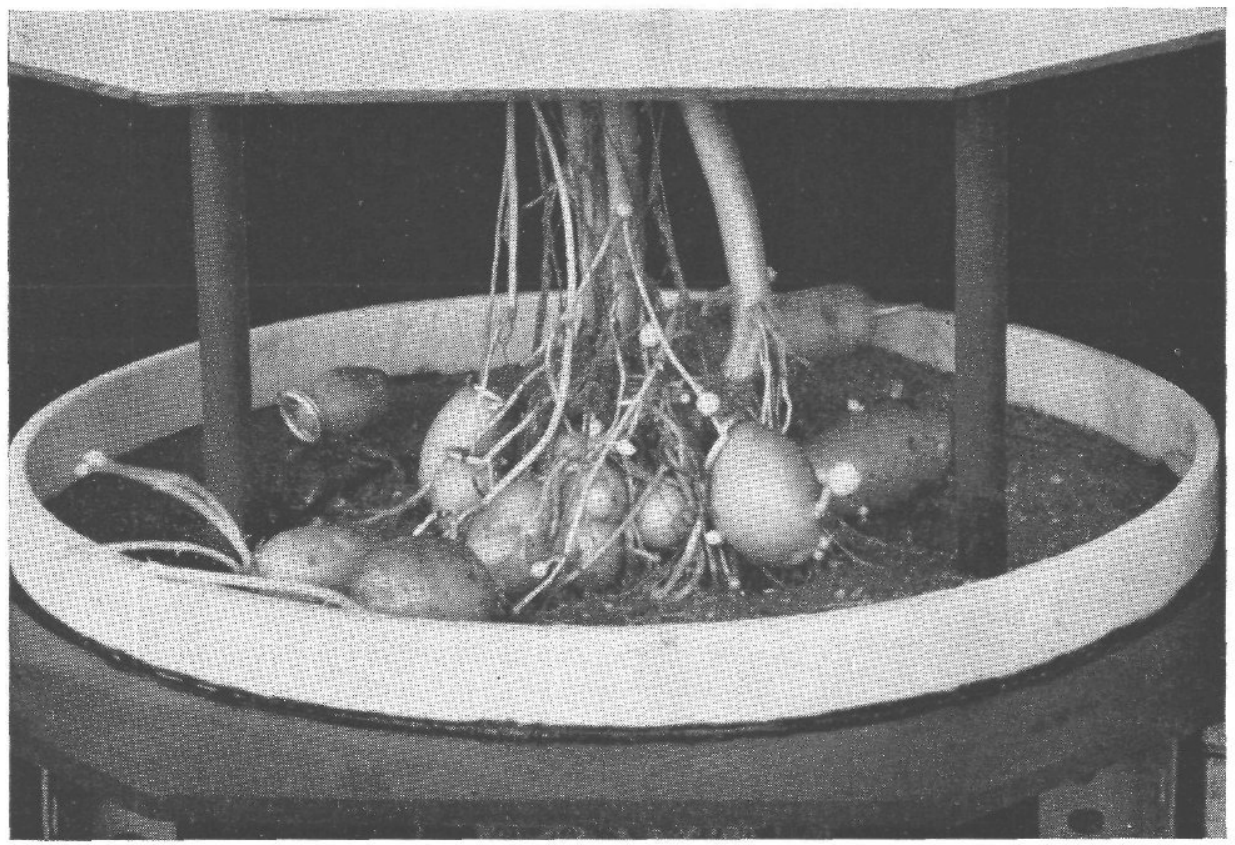

Авв. 1. Bildung von neuen Seitenknollen an Stolonen mit grossen apikalen Knollen nach Hitzebehandlung ( $32^{\circ} \mathrm{C}$ während 2 Wochen); die apikalen Knollen zeigen ebenfalls $Z$ wiewuchserscheinungen. Die Pflanzen wurden auf einer Nährlösung in einem Klimaraum gezogen. Vor und nach der Hitzebehandlung betrug die Temperatur $16^{\circ} \mathrm{C}$; Sorte Bintje

Fig. 1. Formation de nouveaux tubercules latéraux après traitement à la chaleur $\left(32^{\circ} \mathrm{C}\right.$ pendant 2 semaines) sur des stolons munis d'un gros tubercule apical; les tubercules apicaux montrent également le phénomène de seconde croissance. Les plantes ont poussé en solution nutritive dans un local de croissance. La température était de $16^{\circ} \mathrm{C}$ avant et après traitement à la chaleur. Var. Bintje

\subsection{Varietal differences}

The influence of temperature on the growth and development of 7 potato varieties was studied in an experiment in the summer of 1961. In this experiment the temperatures $\left(16,22\right.$ and $\left.27^{\circ} \mathrm{C}\right)$ were maintained from emergence to the final lifting. All varieties showed second-growth at $27^{\circ} \mathrm{C}$, while second-growth rarely occurred at $16^{\circ} \mathrm{C}$. The varieties Bintje, Eigenheimer and Gineke had the highest percentages of secondgrowth: $50-60 \%$ (TABLE 4$)$.

The total number of tubers of the first generation gives a somewhat confusing picture as more tubers are initiated in the first phase of development at low temperatures than at higher ones; however, at temperatures as high as $27^{\circ} \mathrm{C}$ more new tubers are 


\section{THE INDUCTION OF SECOND-GROWTH IN POTATO TUBERS}

FIG. 2. Stem elongation at different temperatures and water supplies; var. Bintje, summer 1962 (for treatments see TABLE 1)

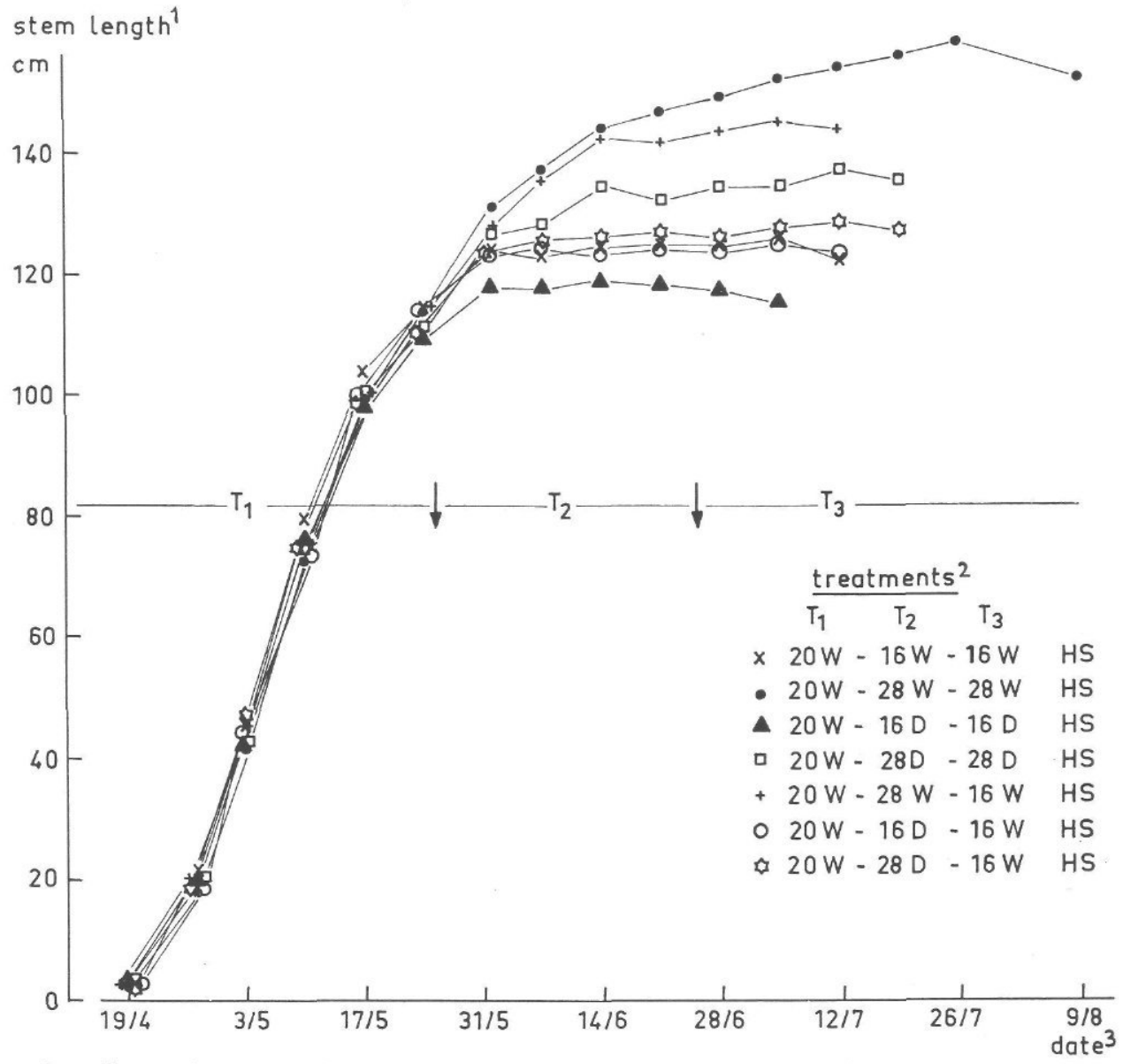

Stengellänge - longueur de tiges.

Behandlungen - traitements.

Datum - date.

Aвв. 2. Stengelwachstum bei verschiedenen Temperaturen und Wassergaben; Sorte Bintje, Sommer 1962 ( $f u ̈ r$ die Behandlungen siehe TABELLE 1)

FIG. 2. Elongation de tiges à différentes températures et apports d'eau; var. Bintje, été 1962 (voir TABLEAU 1 pour les traitements)

initiated later in development (TABLE 1). The total number of tubers of the first generation is the result of both these effects. 
FIG. 3. Senescence at different temperatures and water supplies; var. Bintje, summer 1962 (for treatments see TABLE 1)

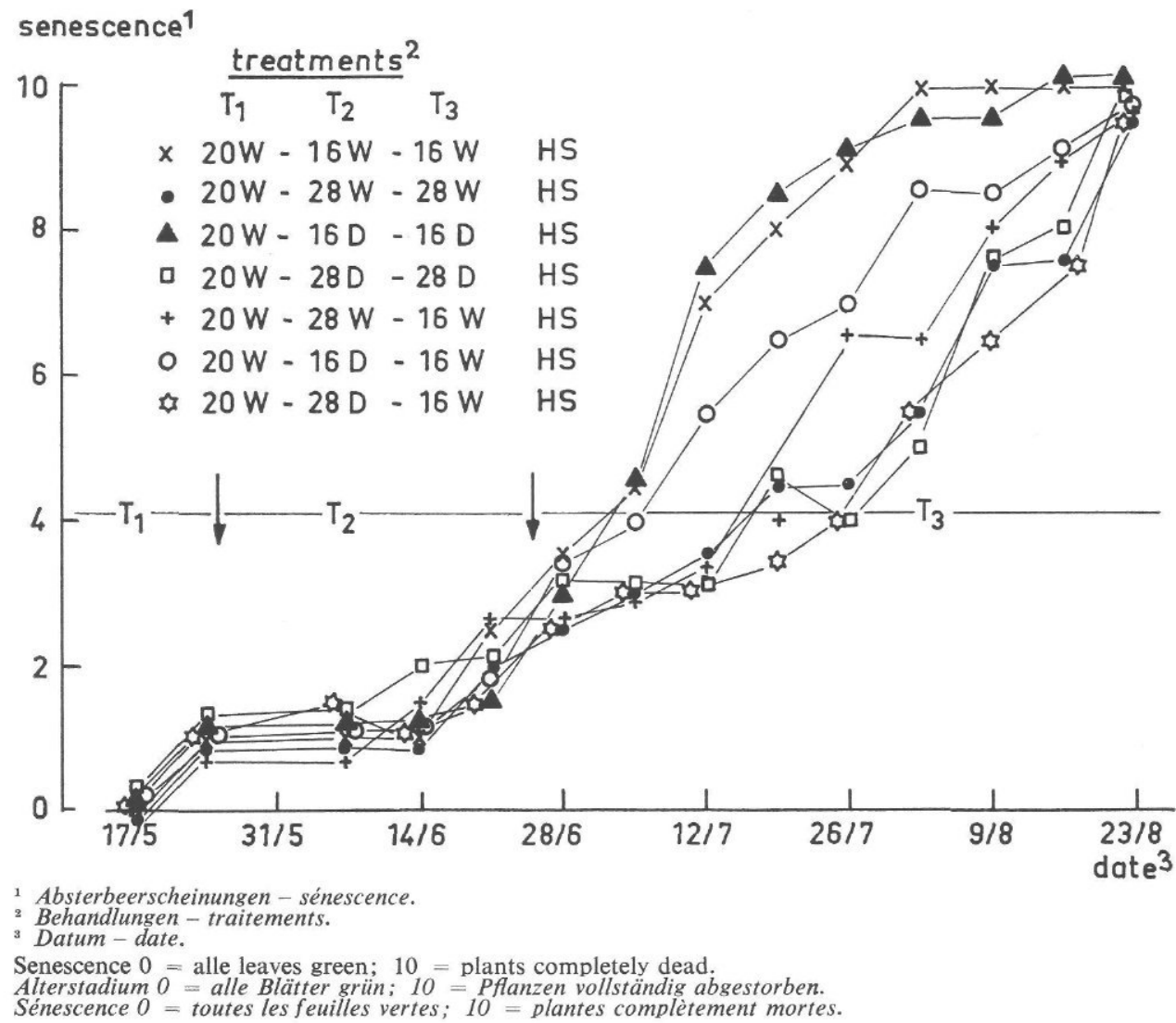

Авв. 3. Altersstadien bei verschiedenen Temperaturen und Wassergaben; Sorte Bintje, Sommer 1962 (für die Behandlungen siehe TABELLE 1)

FIG. 3. Sénescence à différentes températures et apports d'eau; var. Bintje, été 1962 (voir TABLEAU 1 pour les traitements)

\section{CONCLUSIONS AND DISCUSSION}

The above experiments clearly show that high temperatures induce second-growth in potato tubers irrespective of the water supply. Drought is not necessary to induce second-growth. A period of drought at a moderate temperature did not cause secondgrowth. These results exclude the second and third possible explanation mentioned in the introduction and support the first, i.e. that dormancy of the tuber commences with tuber initiation and that this dormancy is broken by high temperature.

High temperature does not only influence the tubers of the first generation already 
Fig. 4. Regrowth of the foliage at the top of the plants after heat treatment; see also FIG. 1

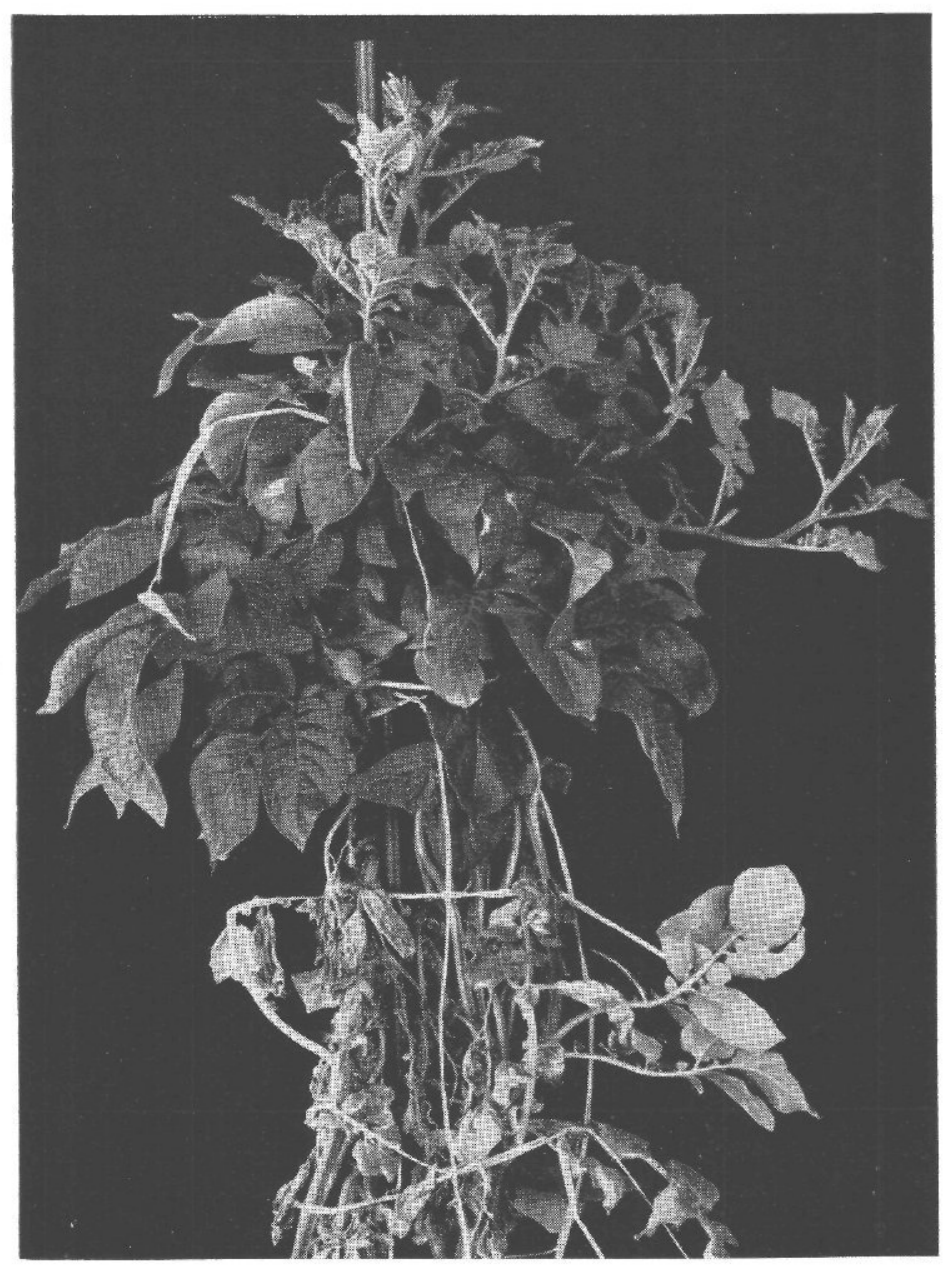

Авв. 4. Neuaustrieb des Blattwerkes in der Wipfelregion der Pflanzen nach Hitzebehandlung; siehe auch ABB. 1

FIG. 4. Recroissance du feuillage dans le sommet de la plante après traitement à la chaleur; voir aussi FIG. 1

present (resulting in sprouting and secondary tuber formation), but can also cause the formation of new tubers of the first generation, branching of the stolons and continued or renewed growth in length of stolons and stems. Schribaux (1921) also observed renewed growth of the foliage together with second-growth in tubers in potato fields. These effects indicate that high temperature reduces the dominance of the apical tubers and partly returns the plant into a "vegetative", non-tuberizing stage.

Europ. Potato J., Vol. 7 (1964) No. 1 (March) 
TABLE 4. Second-growth in potato tubers; seven varieties, summer 1961

\begin{tabular}{|c|c|c|c|c|c|c|c|c|}
\hline \multirow{2}{*}{$\begin{array}{c}\text { Variety } \\
\text { Sorte } \\
\text { Variété }\end{array}$} & \multirow{2}{*}{$\begin{array}{c}\text { Tempera- } \\
\text { ture } \\
\text { Temperatur } \\
\text { Temperature } \\
\left({ }^{\circ} \mathrm{C}\right)\end{array}$} & \multirow{2}{*}{$\begin{array}{c}\text { No. of } \\
\text { plants } \\
\text { Anzahl } \\
\text { Pflanzen } \\
\text { Nombre de } \\
\text { plantes }\end{array}$} & \multicolumn{5}{|c|}{$\begin{array}{c}\text { No. of tubers of 1st generation - Anzahl Knollen der 1. Generation } \\
\text { nombre de tuberc. de lre génération }\end{array}$} & \multirow{2}{*}{$\begin{array}{c}\% \text { second- }^{-} \\
\text {growth } \\
\% \text { Zwie- } \\
\text { wuchserschei- } \\
\text { nungen } \\
\% \text { seconde }^{1} \\
\text { croissance }^{1}\end{array}$} \\
\hline & & & $\begin{array}{l}\text { unsprouted } \\
\text { ungekeimte } \\
\text { non germés }\end{array}$ & $\begin{array}{l}\text { sprouted } \\
\text { gekeimte } \\
\text { germés }\end{array}$ & $\begin{array}{c}\text { primary } \\
\text { primäre } \\
\text { primaires }\end{array}$ & $\begin{array}{l}\text { bottlenecks } \\
\text { hantelförmige } \\
\text { goulots de } \\
\text { bouteille }\end{array}$ & total & \\
\hline \multirow[t]{3}{*}{ Eersteling } & 16 & 4 & 41 & 0 & 0 & 0 & 41 & 0,0 \\
\hline & 22 & 4 & 23 & 2 & 0 & 0 & 25 & 8,0 \\
\hline & 27 & 4 & 19 & 6 & 0 & 9 & 34 & 44,1 \\
\hline \multirow[t]{3}{*}{ Bintje } & 16 & 4 & 49 & 0 & 0 & 2 & 51 & 3,9 \\
\hline & 22 & 4 & 44 & 0 & 0 & 0 & 44 & 0,0 \\
\hline & 27 & 4 & 20 & 5 & 11 & 16 & 52 & 61,5 \\
\hline \multirow[t]{3}{*}{ Eigenheimer } & 16 & 4 & 60 & 0 & 0 & 0 & 60 & 0,0 \\
\hline & 22 & 4 & 44 & 2 & 2 & 4 & 52 & 15,4 \\
\hline & 27 & 4 & 32 & 4 & 22 & 12 & 70 & 54,3 \\
\hline \multirow[t]{3}{*}{ Gineke } & 16 & 4 & 47 & 0 & 0 & 0 & 47 & 0,0 \\
\hline & 22 & 4 & 45 & 0 & 0 & 1 & 46 & 2,2 \\
\hline & 27 & 4 & 16 & 8 & 8 & 2 & 34 & 52,9 \\
\hline \multirow[t]{3}{*}{ Alpha } & 16 & 4 & 43 & 0 & 0 & 1 & 44 & 2,3 \\
\hline & 22 & 4 & 49 & 0 & 3 & 2 & 54 & 9,3 \\
\hline & 27 & 4 & 42 & 5 & 5 & 8 & 60 & 30,0 \\
\hline \multirow[t]{3}{*}{ Dekama } & 16 & 3 & 27 & 0 & 0 & 3 & 30 & 10,0 \\
\hline & 22 & 3 & 22 & 0 & 2 & 2 & 26 & 15,4 \\
\hline & 27 & 3 & 9 & 0 & 2 & 5 & 16 & 43,8 \\
\hline \multirow[t]{3}{*}{ Up-to-Date } & 16 & 6 & 56 & 1 & 0 & 0 & 57 & 1,8 \\
\hline & 22 & 6 & 47 & 1 & 3 & 5 & 56 & 16,1 \\
\hline & 27 & 6 & 25 & 4 & 3 & 7 & 39 & 35,9 \\
\hline
\end{tabular}

1 See table 1 - siehe tabelle 1 - voir tableau 1.

TABELLE 4. Zwiewuchserscheinungen an Kartoffelknollen; sieben Sorten, Sommer 1961

TABLEAU 4. Seconde croissance dans les tubercules de pomme de terre; sept variétés, été 1961

Any condition (e.g. long days, high nitrogen supply, high temperature) delaying tuber formation and promoting stem and stolon elongation will stimulate the induction of second-growth in potato tubers. However, if tuber growth is already well established, a strong influence will be necessary to return the plant from the tuber-forming stage to a more "vegetative" stage; high temperature can "break" dormancy and remove the dominance of the apical tubers of the first generation.

Drought did not induce or promote second-growth in our experiments. This result seems to contradict the observation that irrigated potato fields often show less secondgrowth than non-irrigated dry ones (see section 1.3). The influence of irrigation or drought on the induction of second-growth may perhaps be explained by the differ- 


\section{THE INDUCTION OF SECOND-GROWTH IN POTATO TUBERS}

ences in temperature: the plants develop slowly during a drought period and the soil will be partly bare for a long time. Bare soil has a higher temperature than soil covered by foliage. The temperature of the foliage is decreased by irrigation (partly depending on the temperature of the water applied) and by transpiration.

Lower leaf and soil temperatures on wet soil (compared with dry soil) were indeed observed in the experiment of 1962 (see section 2.2). These differences in leaf and soil temperature may be larger in potato fields. COREY and MEYERs (1955) found a significantly lower soil temperature with short-frequency than with long-frequency irrigation. The influence of air and soil temperature on the induction of second-growth will be discussed in a further paper.

Thus, irrigation will indirectly counteract the induction of second-growth by decreasing temperature. Some authors, however, mention an increase in second-growth by irrigation. This may be caused by starting irrigation when second-growth has already been initiated but a large water supply will favour the growth of foliage; drought, however, will inhibit elongation of stems and stolons. To some extent, therefore, drought might favour tuberization and counteract the occurrence of second-growth. In our experiments more second-growth after a heat treatment has been occasionally observed in plants on wet soil than in those on dry soil. KRAUS (1945) and COREY and MEYERS (1955) showed that in certain instances uniform irrigation of the variety Russet Burbank increased the incidence of knobby tubers. LAFERRIERE (1954, cited by SPARKs, 1958) found in greenhouse tests that potato plants grown with roots extending into water produced knobby tubers, whereas some plants grown with roots subjected to severe drought did not produce abnormal tubers; the author stated that temperature alone may induce knobby second-growth.

\section{SUMMARY}

Experiments were carried out in glasshouses to induce second-growth in potato tubers under controlled conditions.

High temperature, irrespective of the water supply, induced second-growth in the tubers; drought did not induce or promote secondgrowth in these experiments. High temperature promoted the formation of new tubers of the first generation, and also branching and continued or renewed length growth of stolons and stems. High temperature temporarily returned the potato plant from a tuberizing stage into a more "vegetative" stage.

\section{ZUSAMMENFASSUNG}

\section{DIE INDUKTION VON ZWIEWUCHSERSCHEINUNGEN AN KARTOFFELKNOLLEN}

1. Es wurden Versuche im Glashaus durchgeführt, um unter kontrollierten Bedingungen Zwiewuchserscheinungen an Kartoffelknollen herbeizuführen.

2. Die Pflanzen wuchsen nach Beginn der Knollenbildung während eines Monats oder bis zum Absterben des Krautes bei verschiedenen
Temperaturen auf $\left(16,22,27-28\right.$ und $\left.32^{\circ} \mathrm{C}\right)$. Die meisten Pflanzen erhielten während der ganzen Versuchsdauer reichlich Wasser, nur die Pflanzen der Trockenheits-Verfahren erhielten kein Wasser, bis Welkeerscheinungen beobachtet wurden. 3. Hohe Temperaturen induzierten, unabhängig von der Wasserzuführung, Zwiewuchserschei- 
nungen an Kartoffelknollen; dagegen wurden in diesen Versuchen bei $16^{\circ} \mathrm{C}$ keine Zwiewuchserscheinungen beobachtet (TABELLEN 1 und 2).

4. Trockenheit induzierte oder förderte den Zwiewuchs nicht (TABELLE 1).

5. Andere Beobachtungen zeigen, daß die Induktion von Zwiewuchsformen bei hohen Temperaturen unter Langtag- ausgeprägter ist als unter Kurztag-Bedingungen; offenbar können auch hohe Stickstoffgaben das Vorkommen von Zwiewuchserscheinungen verursachen.

6. Hohe Temperatur verringert nicht nur die

Keimruhe und die Dominanz der apikalen Knollen der ersten Generation, sondern fördert auch die Bildung von neuen Knollen der ersten Generation (ABB. 1) und die Verzweigung der Stolonen. Ferner bewirkt hohe Temperatur die Fortsetzung oder Erneuerung des Längenwachs- tums der Stolonen und der Stengel (TABelle 3, ABB. 2). Dank diesem fortgesetzten oder erneuten Wachstum der Triebe (ABB. 4) starb das Blattwerk bei hohen Temperaturen später ab (ABB. 3).

7. Hohe Temperatur bewirkte bei der Kartoffelpflanze die Rückkehr vom knollenbildenden in ein mehr "vegetatives" Stadium.

8. In einem Versuch mit 7 Sorten zeigten alle Sorten Zwiewuchserscheinungen; die Sorten Bintje, Eigenheimer und Gineke wiesen den größten Prozentsatz an Zwiewuchserscheinungen auf (TABELle 4),

9. Einige Forscher erwähnen die Tatsache, daß Bewässerung das Vorkommen von Zwiewuchs verhütet oder vermindert; die Ursache hierzu mag in einer Abnahme der Temperatur in Boden und Blattwerk liegen.

\section{RÉSUMÉ}

\section{L'INDUCTION DE LA SECONDE CROISSANCE DANS LES TUBERCULES DE POMME DE TERRE}

1. Des expériences ont été réalisées en serre, en conditions contrôlées, dans le but de provoquer une seconde croissance dans des tubercules de pomme de terre.

2. Les plantes ont été soumises, après le début de la tubérisation, à différentes températures (16, $22,27-28$ ou $32^{\circ} \mathrm{C}$ ) durant un mois ou jusqu'à ce que le feuillage meure. La plupart des plantes recevaient de l'eau en quantités suffisantes pendant l'expérience entière; seules les plantes des traitements de sécheresse ne recevaient pas d'eau jusqu'à ce que le flétrissement soit observé.

3. La haute température, indépendamment des apports d'eau, induit la seconde croissance des tubercules; presqu' aucun phénomène de seconde croissance n'a été observé à $16^{\circ} \mathrm{C}$ dans ces essais (TABLEAUX 1 et 2 ).

4. La sécheresse n'induisait ou ne favorisait pas la seconde croissance (TABLEAU 1).

5. D'autres observations indiquent que l'induction de la seconde croissance par la haute température est plus prononcée sous des conditions de jours longs plutôt que de jours courts; évidemment un aport élevé d'azote peut aussi provoquer l'apparition du phénomène de seconde croissance.

6. La haute température non seulement diminue

la dormance et la dominance des tubercules apicaux de la première génération, mais aussi favorise la formation de nouveaux tubercules de première génération (FIG. 1), la ramification des stolons, et continue ou rétablit la croissance des stolons et tiges (TABLEAU 3, FIG. 2). En raison de la poursuite ou du rétablissement de la croissance des sommets (FIG. 4), le feuillage meurt plus tard à hautes températures (FIG. 3).

7. Une haute température fait repasser le plant de pomme de terre d'un stade de tubérisation en un stade plus végétatif.

8. Dans un essai avec sept variétés, toutes ont manifesté le phénomène de seconde croissance au température élevée; les variétés Bintje, Eigenheimer et Gineke ont montré le plus haut pourcentage de seconde croissance (TABLEAU 4).

9. Plusieurs chercheurs mentionnent le fait que

l'irrigation prévient ou réduit l'apparition de la seconde croissance; ceci peut être dû à la diminution de la température du feuillage et du sol. 


\section{THE INDUCTION OF SECOND-GROWTH IN POTATO TUBERS}

\section{REFERENCES}

BAARS, C. (1962): Beregening van aardappelen. Opbrengstverhoging door beregening. De Landbode. 16,473

Bushnell, J., and F. A. Welton (1931): Some effects of straw mulch on yield of potatoes. J. Agric. Res. 43, 837-845.

Claver, F. K. (1960): Efectos del acido giberelico y de la hybrazida maleica sobre la tuberizacion de la papa. Phyton. 15, 29-35.

Corey, G. L., and V. I. Meyers (1955): Irrigation of Russet Burbank potatoes in Idaho. Idaho Agr. Exp. Sta. Bull. No. 246, 1-20.

FisCHNICH, O. (1959): Folgen der Witterung 1959 für Ernte und Lagerung. Der Kartoffelbau. 10, Heft 10.

KraUS, J. E. (1945): Influence of certain factors on second growth on Russet Burbank potatoes. Amer. Potato J. 22, 134-142.

LAFERRIERE, L. (1954): Some factors affecting knobby second growth of Idaho Russet Burbank potatoes. Thesis. M.S. Univ. Idaho, Moscow, Idaho, U.S.A.

Laplaud, M. (1905): Pommes de terre de deuxième génération. J. d'Agric. prat. 9 (N.S.), 598-600.

LIPPERT, L. F., L. RAPPAPORT and H. TIMM (1958): Systemic induction of sprouting in white potatoes by foliar applications of gibberellin. Plant Phys. 33, 132-133.

Lugt, C. (1960): Second-growth phenomena. Europ. Potato J. 3, 307-324.

(1961): Second-growth phenomena. Proc. Ist triennial Conf. EAPR, Germany, 1960. 243-244.

Murphy, P. A. (1936): Some effects of drought on potato tubers. Empire J. Exp. Agric. 4, 230-246.

Nielson, L. W., and W. C. Sparks (1953): Bottleneck tubers and jelly-end rot in the Russet Burbank potato. Idaho Agric. Exp. Sta. Res. Bull. No. 23, 1-24.

Schribaux, M. (1921): Sur les cultures de pommes de terre dans la Loire. C. R. Acad. d'Agric. France. 7, 775-780.

Sparks, W. C. (1958): Abnormalities in the potato due to water uptake and translocation. Amer. Potato J. 35, $430-436$.

STEINECK, O. (1959): Untersuchungen an durchwachsenen Kartoffelknollen. Pflanzenschutzberichte. 9, 80-99. 